\title{
Challenge of Isolated Sputum Cells Supports in vivo Origin of Intolerance Reaction to Aspirin/ Non-Steroidal Anti-Inflammatory Drugs in Asthma
}

\author{
Ai Higashi ${ }^{a, d}$ Maria Kumlin ${ }^{a, c, d}$ Noritaka Higashi ${ }^{a, d}$ Kameran Daham ${ }^{b, d}$ \\ Flora Gaber ${ }^{a, d} \quad$ Agneta Lindeberg $^{\text {b, d }} \quad$ Anna James ${ }^{a, b, d}$ Maria Skedinger ${ }^{b, d}$ \\ Ingrid Delin ${ }^{a, d}$ Pär Gyllfors ${ }^{b, d}$ Sven-Erik Dahlén ${ }^{a, d}$ Barbro Dahlén ${ }^{b, d}$ \\ aUnit of Experimental Asthma and Allergy Research, The National Institute of Environmental Medicine, \\ ${ }^{b}$ Division of Respiratory Medicine and Allergy, Department of Medicine at Karolinska University Hospital Huddinge, \\ and 'Sophiahemmet University College, ${ }^{\mathrm{d} C e n t r e ~ f o r ~ A l l e r g y ~ R e s e a r c h, ~ K a r o l i n s k a ~ I n s t i t u t e t, ~ S t o c k h o l m, ~ S w e d e n ~}$
}

\section{Key Words}

Ex vivo stimulation - Sputum cells · Cysteinyl leukotriene • Lysine-aspirin $\cdot$ Aspirin-intolerant asthma

\begin{abstract}
Background: There is no in vitro test to diagnose aspirinintolerant asthma (AIA). The aim of this study was to test if challenge with aspirin of sputum cells from subjects with AIA triggers the release of cysteinyl leukotrienes (CysLTs), known to be mediators of bronchoconstriction in AIA. Methods: Sputum induction was performed at baseline and at another visit $2 \mathrm{~h}$ after a lysine-aspirin bronchoprovocation in $10 \mathrm{sub}$ jects with AIA and 9 subjects with aspirin-tolerant asthma (ATA). The isolated sputum cells were incubated for ex vivo challenge. Results: Release of CysLTs by sputum cells from patients with AIA was not induced by lysine-aspirin ex vivo, neither when cells were collected at baseline nor in sputum cells recovered after lysine-aspirin-induced bronchoconstriction, whereas release of CysLTs from sputum cells was triggered by an ionophore on both occasions. However, the CysLT levels elicited by the ionophore were higher in the AIA group both at baseline (AIA vs. ATA: 3.3 vs. $1.6 \mathrm{ng} / \mathrm{million}$ cells; $p<0.05)$ and after the lysine-aspirin bronchoprovoca-
\end{abstract}

tion (3.9 vs. $1.7 \mathrm{ng} /$ million cells; $\mathrm{p}<0.05$ ). This difference in the amount of CysLTs released between the groups appeared to be related to the number of eosinophils. Conclusions: Intolerance to aspirin could not be triggered in sputum cells isolated from subjects with AIA. Together with the previous inability to demonstrate intolerance to non-steroidal anti-inflammatory drugs in isolated blood cells, these results support the requirement of tissue-resident cells in the adverse reaction. However, ex vivo stimulation of sputum cells may be developed into a new test of capacity for LT release in inflammatory cells recovered from airways.

Copyright $\odot 2012$ S. Karger AG, Basel

\section{Introduction}

The clinical syndrome of aspirin-intolerant asthma (AIA) is characterized by the 'aspirin triad', i.e. aspirin intolerance, bronchial asthma and chronic rhinosinusitis with nasal polyposis $[1,2]$. All non-steroidal anti-inflammatory drugs (NSAIDs) that non-selectively inhibit cy-

A.H. and M.K. contributed equally to this work.

\section{KARGER}

Fax +41613061234

E-Mail karger@karger.ch

www.karger.com (c) 2012 S. Karger AG, Basel

$1018-2438 / 12 / 1583-0299 \$ 38.00 / 0$

Accessible online at:

www.karger.com/iaa
Correspondence to: Dr. Barbro Dahlén

Division of Respiratory Medicine and Allergy, Department of Medicine

Karolinska University Hospital Huddinge, C2 88

SE-14186 Stockholm (Sweden)

Tel. +4685858 6734, E-Mail barbro.dahlen@ki.se 
clooxygenase (COX)-1 induce bronchoconstriction in patients with AIA [2], whereas COX-2-specific inhibitors (coxibs) are tolerated in the vast majority of cases [3-6]. The most accepted explanation for this rapidly occurring adverse reaction to NSAIDs is that inhibition of biosynthesis of prostaglandin (PG) $\mathrm{E}_{2}$ somehow triggers the intolerance reaction $[1,2]$.

There is evidence that cysteinyl leukotrienes (CysLTs) play a key role in AIA. Thus, urinary leukotriene (LT) $\mathrm{E}_{4}$ concentrations are significantly elevated at baseline in AIA patients and increase further after aspirin challenge [7-12]. There are also higher baseline levels of CysLTs in saliva, ex vivo stimulated blood and induced sputum samples collected from AIA patients as compared to patients with aspirin-tolerant asthma (ATA) [13]. In further support of the pivotal role of CysLTs in the pathophysiology of AIA, anti-LT drugs substantially block aspirin-induced bronchoconstriction $[14,15]$ and have beneficial therapeutic effects on the clinical symptoms of asthma in patients with AIA $[16,17]$.

However, it is less clear which cellular reactions explain the increased biosynthesis of CysLTs in AIA. Studies of different inflammatory cells in the blood have so far failed to produce consistent support for specific NSAIDinduced ex vivo activation of cells from subjects with AIA $[18,19]$. Isolated cells from sputum are currently the source of cells that can most easily be recovered from the lower airways of patients with asthma, and they have previously been used to study lymphocyte activation and cytokine release ex vivo [20, 21]. Since AIA patients react with bronchoconstriction in response to lysine-aspirin bronchoprovocation, our hypothesis was that the aspirin/ NSAID intolerance demonstrated in vivo might be maintained if sputum cells were challenged by lysine-aspirin ex vivo. Moreover, to the best of our knowledge this is the first time sputum cells from subjects with asthma have been used to investigate the release of CysLTs ex vivo.

The study design included a bronchoprovocation-verified diagnosis of AIA at the time of the study, ex vivo challenge of isolated sputum cells and comparison with the responses in a matched group of subjects with ATA. The effects of lysine-aspirin were compared with challenge with calcium ionophore A23187, which is a standard means to trigger LT biosynthesis.

In addition to the triggering of intolerance reactions by NSAIDs in subjects with AIA, another peculiarity of the syndrome is that there is a refractory period for up to a week after positive reactions to aspirin [22]. This desensitisation phenomenon is sometimes used as treatment [2]. The present study therefore included collection of sputum cells both at baseline and $2 \mathrm{~h}$ after a positive reaction to inhaled lysine-aspirin had been triggered. This design was selected to test the hypothesis that the airway cells recovered in sputum after the in vivo challenge would be refractory to aspirin-induced ex vivo release of CysLTs, thereby reflecting the in vivo desensitisation.

The broader context of the study was to explore new methods for the diagnosis of aspirin/NSAID intolerance. Diagnosis based on medical history alone is unreliable $[1$, $2,23]$, and neither is there a validated and predictive in vitro test for aspirin hypersensitivity. Recent guidelines recommend that the diagnosis of AIA should be confirmed with an aspirin bronchoprovocation test [23]. However, appropriate provocation tests are time-consuming and can only be performed in a limited number of experienced clinical centres. The overall aim of the study was therefore to explore the potential of using sputum cells for development of a new diagnostic in vitro test.

\section{Methods}

Subjects

The study hypotheses were tested in the present exploratory sub-study of a trial for which other end points have been published elsewhere [13]. The sputum cells were collected from 19 non-smoking subjects with chronic asthma, recurrent rhinosinusitis and/or nasal polyps and a suspicion of intolerance to NSAID (table 1). All subjects had a forced expiratory volume in $1 \mathrm{~s}\left(\mathrm{FEV}_{1}\right) \geq 70 \%$ of predicted and had stable asthma. Subjects who had had an asthma exacerbation or lower respiratory tract infection within the previous 6 weeks were excluded. The study was approved by the local ethics committee at the Karolinska Institutet (Dnr 518/03), and the subjects gave written informed consent. Before each visit, subjects were instructed to refrain from taking inhaled short-acting $\beta_{2}$-agonists for $6 \mathrm{~h}$, inhaled ipratropium for $12 \mathrm{~h}$, theophylline for $24 \mathrm{~h}$, inhaled long-acting $\beta_{2}$-agonists, combination treatments, cromoglycate, montelukast or short-acting antihistamine drugs for $48 \mathrm{~h}$ and long-acting antihistamines for 5 days.

\section{Study Design}

After an initial screening visit including physical examination and spirometry, eligible patients were enrolled to a baseline visit (visit 1), followed by a lysine-aspirin provocation visit (visit 2) 3-10 days later. At the second visit, subjects underwent lysineaspirin bronchoprovocation according to the European Academy of Allergy and Clinical Immunology Organisation/Global Allergy and Asthma European Network guidelines [23] as previously described [13]. On the basis of the lysine-aspirin bronchoprovocation test results, subjects demonstrating a provocative dose causing a $20 \%$ decrease in $\mathrm{FEV}_{1}$ for lysine-aspirin were classified as AIA, whereas non-responders to the highest cumulative dose of lysine-aspirin were classified as ATA (table 1). 
Table 1. Patient characteristics

\begin{tabular}{lcc}
\hline & AIA $(\mathrm{n}=10)$ & ATA $(\mathrm{n}=9)$ \\
\hline Females/males, $\mathrm{n}$ & $6 / 4$ & $7 / 2$ \\
Mean age (range), years & $46.9(35-63)$ & $44.4(27-56)$ \\
Mean FEV $_{1} \pm \mathrm{SD}$, litres & $2.7 \pm 0.7$ & $3.0 \pm 0.7$ \\
Mean FEV $_{1} \pm \mathrm{SD}$ \% predicted & $85.5 \pm 13.2$ & $98.8 \pm 12.8$ \\
Median baseline urinary LTE $_{4}(\mathrm{IQR}), \mathrm{ng} / \mathrm{mmol}$ creatinine & $89.7(65.4-123)^{*}$ & $40.8(35.0-51.9)$ \\
\hline Treatments & 8 & 6 \\
Inhaled corticosteroids $(\mathrm{ICS}), \mathrm{n}_{\text {Median daily ICS dose }^{\mathrm{a}} \text { among those treated (range), } \mu \mathrm{g}}$ & $695(150-1,500)^{*}$ & $360(200-400)$ \\
LT receptor antagonist, $\mathrm{n}$ & 3 & 0 \\
\hline
\end{tabular}

${ }^{*} \mathrm{p}<0.05$ compared with ATA (Mann-Whitney rank-sum test).

a Dose of budesonide equivalents.

Sputum Induction and Processing

Sputum was collected at the baseline visit (visit 1 ) and $2 \mathrm{~h}$ after the end of lysine-aspirin bronchoprovocation at visit 2 .

Sputum induction and processing was performed essentially according to the European Respiratory Society guidelines [24]. The weight of all sputum samples was more than $1 \mathrm{~g}$, and 4 volumes of $0.1 \%$ dithiothreitol (DTT) were added together with 4 volumes of PBS, making a final DTT concentration of $0.05 \%$. After centrifugation of the sputum samples, the supernatants were stored at $-80^{\circ} \mathrm{C}$ until being assayed for CysLTs. Isolated sputum cells obtained from the cell pellet after the centrifugation were further processed for ex vivo stimulations as described in the next section. Cytospins were also prepared from the cell pellet and stained with May-Grünwald Giemsa (Sigma-Aldrich Co.). Cell viability was estimated by the trypan blue dye exclusion method [24]. The sputum eosinophil counts are expressed as a percentage of the total number of non-squamous cells.

\section{Ex vivo Incubation of Isolated Sputum Cells}

Incubations were performed with 2 million non-squamous sputum cells resuspended in $1 \mathrm{ml}$ of $\mathrm{PBS}, \mathrm{pH} 7.4$, pre-warmed for 2 min and subsequently incubated with lysine-aspirin $(100 \mu \mathrm{M})$ or calcium ionophore A23187 $(2.5 \mu \mathrm{M})$. Incubations with $0.9 \%$ saline or ethanol were used as solvent controls for lysine-aspirin and ionophore A23187, respectively. After $15 \mathrm{~min}$, the incubations were put on ice for $15 \mathrm{~min}$ followed by centrifugation at $400 \mathrm{~g}$ for $10 \mathrm{~min}$. The resulting cell-free medium was stored at $-80^{\circ} \mathrm{C}$ until being assayed for CysLTs.

\section{Measurement of CysLTs in Incubations of Isolated Sputum}

Cells ex vivo

The cell-free medium supernatants from ex vivo stimulated sputum cells were subjected to solid-phase extraction on $100-\mathrm{mg}$ Isolute ${ }^{\circledR} \mathrm{C} 18$ silicic acid columns (International Sorbent Technology Ltd., Ystrad Mynach, UK). The columns were eluted with methanol, and levels of CysLTs were analysed in serially diluted aliquots of the respective samples by enzyme immunoassay (EIA; Cayman Chemical Co., Ann Arbor, Mich., USA) as previously described [13]. Briefly, each data point is derived from means of replicate analysis of samples, using only data obtained within the linear portion of the displacement curve. Results are expressed as percentage recovery of samples spiked with radiolabelled $\mathrm{LTE}_{4}$. The assay detection limit was $7.8 \mathrm{pg} / \mathrm{ml}$, with intra-assay and inter-assay variations being less than 10 and $12 \%$, respectively. The amounts of CysLTs released from ex vivo stimulated sputum cells are expressed as nanograms per million cells. There were no significant differences in the levels of CysLTs in incubations with saline as compared to ethanol (not shown). Control data in figure 1 represent saline incubations.

Measurements of CysLTs in Sputum Supernatants and Urine

Measurements were performed by EIA using the same method as for sputum cells [13]. Final concentrations are presented as picograms per millilitre and nanograms per millimole of creatinine for sputum supernatants and urine, respectively. For measurements in sputum supernatants, $0.05 \%$ DTT was added to the EIA buffer also for the standard curve in order to standardise for possible effects of DTT on the measurements.

\section{Statistical Analysis}

Statistical analysis was performed using Sigma Stat 3.01 (SPPS Inc., Chicago, Ill., USA), with results presented as the median and interquartile range or mean $\pm \mathrm{SD}$, as appropriate. All results of sputum ex vivo experiments were analysed using the non-parametric Mann-Whitney rank-sum test. Post hoc analysis Dunnett's test was applied to all significant $(\mathrm{p}<0.05)$ variables derived from the Friedman repeated-measure analysis of variance on rank test. A p value of $<0.05$ was considered significant.

\section{Results}

\section{Baseline Characteristics of Subjects}

The subjects with AIA and ATA, as defined by the result of the lysine-aspirin provocation test at visit 2, had very similar baseline characteristics, although the AIA 


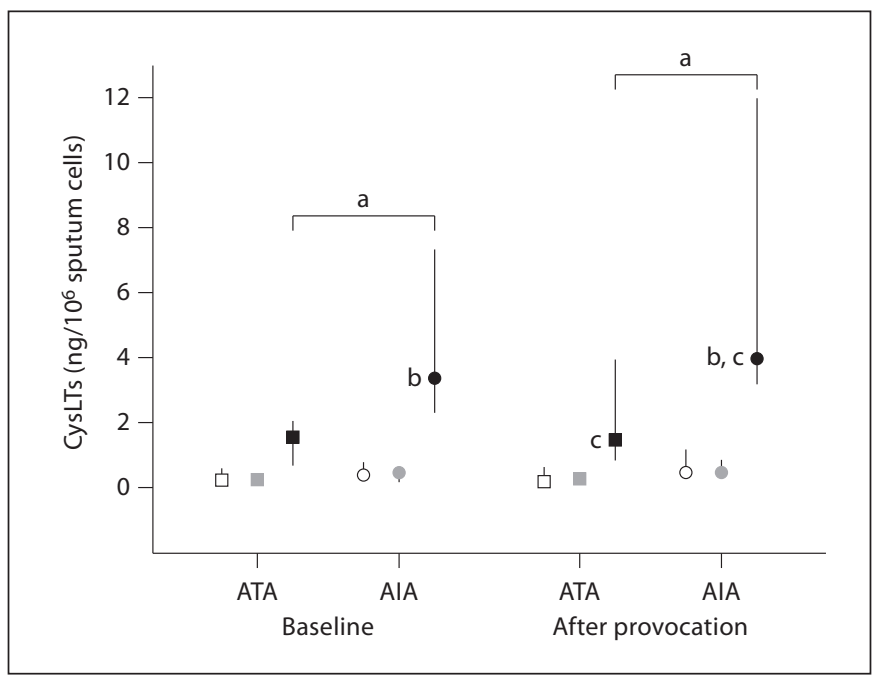

Fig. 1. Levels of CysLTs in medium of ex vivo stimulated isolated sputum cells from subjects with AIA $(n=10)$ and ATA $(n=9)$. Shown are median values (interquartile range) after 15-min incubations with saline (control; open symbols), lysine-aspirin (100 $\mu \mathrm{M}$; grey symbols) or A23187 (2.5 $\mu \mathrm{M}$; black symbols) in samples collected at the baseline visit or $2 \mathrm{~h}$ after the end of an inhaled lysine-aspirin provocation. ${ }^{\mathrm{a}} \mathrm{p}<0.05$ : AIA versus ATA; ${ }^{\mathrm{b}} \mathrm{p}<0.05$ : A23187 versus lysine-aspirin; ${ }^{\mathrm{C}} \mathrm{p}<0.05$ : A23187 versus control.

group used slightly higher doses of inhaled corticosteroids (table 1). The AIA group had higher baseline values of urinary $\mathrm{LTE}_{4}$ as compared to the ATA group (table 1), confirming the characteristic phenotype of AIA [2, 7-12].

Consistent with data from our previous study [13], the CysLT levels in the supernatants of the induced sputum samples from the AIA group were higher than those from the ATA group at baseline (visit 1 ) as well as after lysineaspirin provocation (visit $2 ; \mathrm{p}<0.05$; table 2 ). However, CysLT levels in sputum supernatants were not increased in either group in samples collected $2 \mathrm{~h}$ after the in vivo lysine-aspirin provocation at visit 2 when compared with baseline values at visit 1 (table 2).

\section{CysLT Release from ex vivo Stimulated Sputum Cells}

Isolated at Baseline

There were detectable levels of CysLTs in the medium of all ex vivo incubations of isolated sputum cells. However, there were no significant changes, as compared to saline controls, in CysLT levels after ex vivo incubation in the presence of lysine-aspirin in either group (fig. 1). Moreover, the levels of CysLTs after exposure to lysineaspirin were not significantly different between the two
Table 2. CysLTs in sputum supernatants

\begin{tabular}{|c|c|c|c|}
\hline & $\begin{array}{l}\text { Baseline CysLTs } \\
\mathrm{pg} / \mathrm{ml}\end{array}$ & $\begin{array}{l}\text { Post-provocation } \\
\text { CysLTs, pg/ml }\end{array}$ & $\begin{array}{l}\mathrm{p} \\
\text { value }\end{array}$ \\
\hline $\operatorname{AIA}(\mathrm{n}=10)$ & $55.2(17.2-128)$ & $61.5(30.8-93.2)$ & 0.791 \\
\hline $\operatorname{ATA}(\mathrm{n}=9)$ & $14.4(8.25-23.8)$ & $14.4(10.6-21.9)$ & 0.965 \\
\hline $\mathrm{p}$ value & $<0.05$ & $<0.05$ & \\
\hline
\end{tabular}

Values represent medians and interquartile ranges. $\mathrm{p}$ values were calculated using the Mann-Whitney rank-sum test.

groups (median values for AIA vs. ATA: 0.43 vs. $0.23 \mathrm{ng} /$ million cells, $\mathrm{p}>0.05$; fig. 1 ).

In contrast, challenge with ionophore A23187 caused a marked increase in CysLT release in sputum cells from AIA subjects $(\mathrm{p}<0.05)$ as compared to stimulation with lysine-aspirin, and a strong tendency to an increase was documented in the ATA group ( $\mathrm{p}=0.093$; fig. 1). However, the ionophore-elicited levels of CysLTs were significantly higher in the AIA group (median values for AIA vs. ATA: 3.3 vs. $1.6 \mathrm{ng} /$ million cells, $\mathrm{p}<0.05$; fig. 1 ).

CysLT Release from ex vivo Stimulated Sputum Cells

Isolated after the Lysine-Aspirin Bronchoprovocation

Sputum cells isolated from induced sputum $2 \mathrm{~h}$ after lysine-aspirin bronchoprovocation at visit 2 also responded with increased CysLT release to challenge with the ionophore A23187, whereas the levels after ex vivo incubation with lysine-aspirin were the same as in the presence of saline or ethanol (fig. 1).

Again, ionophore A23187 caused significantly greater CysLT release from ex vivo stimulated sputum cells from the AIA group than from the ATA group (median values for AIA vs. ATA: 3.9 vs. $1.7 \mathrm{ng} /$ million cells, $\mathrm{p}<0.01$; fig. 1). However, there was no significant difference between the responses to A23187 on the two occasions within either group (fig. 1).

\section{CysLT Release from ex vivo Sputum Cells Related to} Sputum Eosinophil Counts

Sputum total cell counts were similar in the two groups, but there was a tendency towards a higher percentage of sputum eosinophils in the AIA group as compared with the ATA group, which reached statistical significance after lysine-aspirin provocation (table 3). However, there was no increase in eosinophil percentage after lysine-aspirin provocation within the groups when compared with baseline values (table 3 ). 
Table 3. CysLTs related to eosinophil counts in sputum

\begin{tabular}{llll}
\hline & AIA & ATA & p value \\
\hline Sputum cell count & & & \\
Baseline eosinophils, \% & $5.7(1.5-13.9)$ & $1.4(0.3-5.1)$ & $>0.05$ \\
Eosinophils after provocation, \% & $5.2(3.3-13.0)$ & $2.0(1.3-3.5)$ & $<0.05$ \\
p value & $>0.05$ & $>0.05$ & \\
\hline Ex vivo stimulation with A23187 & & & \\
Baseline CysLTs, ng/106 eosinophils & $101(47.9-192)$ & $115(48.0-898)$ & $>>0.05$ \\
CysLTs after provocation, ng/106 eosinophils & $88.3(67.3-173)$ & $56.6(53.4-78.2)$ & $>>0.05$ \\
p value & $>>0.05$ & $>>0.05$ & \\
\hline
\end{tabular}

Values represent medians and interquartile ranges.

Moreover, when the amounts of CysLTs released from ionophore A23187-stimulated sputum cells were adjusted for eosinophil counts, the values for CysLTs in nanograms per million eosinophils were not different between the two groups (ATA and AIA) or the two visits (baseline and after provocation; table 3 ).

\section{Discussion}

We hypothesized that aspirin/NSAID intolerance might be maintained in sputum cells recovered from the lower airways of patients with AIA and challenged with aspirin ex vivo. However, lysine-aspirin challenge could not induce CysLT production above control in the sputum cells isolated from the AIA patients. The same AIA subjects had lysine-aspirin-induced bronchoconstriction at the time of the study with increased excretion of urinary $\mathrm{LTE}_{4}$ when challenged in vivo [13], providing unequivocal confirmation that they had the correct phenotype at the time of the study.

The study therefore represents yet another negative attempt to obtain an in vitro test for AIA. Previous data with several other inflammatory cells from subjects with AIA have failed to show specific activation ex vivo by exposure to NSAIDs $[18,19,25,26]$. Suggestions of aspirininduced activation of platelets from patients with AIA [27] have not been replicated [18]. Moreover, despite in vivo evidence that mast cell activation occurs during aspirin-induced bronchoconstriction [9-11, 28-32], Wang et al. [33] could not trigger activation of blood-derived mast cells from subjects with AIA by ex vivo exposure to aspirin. The present study therefore gives support to the concept that aspirin/NSAID intolerance is a unique and not yet completely understood in vivo reaction in which presumably many cells interact in a complex fashion that, however, requires contact with the target tissue in the airways. Perhaps the intolerance reaction includes collaboration between resident and circulating cells.

Support of the tissue factor in the intolerance reaction is provided by challenge studies in which selective administration of aspirin to nasal or bronchial airways results in local but not systemic reactions [34]. Likewise, intravenous injection of lysine-aspirin in subjects with AIA produces bronchoconstriction and release of CysLTs but not systemic anaphylactoid reactions [11]. Further indications of a local tissue defect are provided by observations that fibroblasts and nasal epithelial cells from subjects with AIA produce less $\mathrm{PGE}_{2}$ than the same cells from subjects with ATA $[35,36]$. It is thus currently believed that the intolerance reaction in AIA involves removal of a protective effect of $\mathrm{PGE}_{2}$ on the inflammatory cells that produce the mediators of bronchoconstriction [2]. Lower levels of local biosynthesis of $\mathrm{PGE}_{2}$ in AIA might therefore explain increased sensitivity to the inhibitory effects of NSAIDs. There are indications that the biosynthesis of $\mathrm{PGE}_{2}$ in airway epithelium is catalysed by COX-1 [37], in line with the apparent tolerance to COX-2 inhibition in patients with AIA.

Another feature of AIA is the specific desensitisation to repeated challenge that occurs following a positive reaction $[2,22]$ and includes diminished LT biosynthesis [38]. However, in the present study, when the sputum cells were challenged with ionophore $2 \mathrm{~h}$ after the aspirin-induced bronchoconstriction, the CysLT release was not diminished compared with the effect of the same challenge at the baseline visit when the subjects had not been exposed to aspirin. Taken together, the failure of sputum 
cells from patients with AIA to be activated by aspirin and the absence of a desensitisation phenomenon suggests that cells present in sputum do not cause the intolerance reaction, at least not alone. Our findings would seem to remove lymphocytes, macrophages, neutrophils and eosinophils from the list of cells suspected to be responsible effectors in the adverse reaction. This does not preclude their participation in long-term events that control the propensity to have an adverse reaction. For example, there are observations suggesting that desensitisation to aspirin may cause chronic changes in the IL-4 pathway $[39,40]$ that may regulate responsiveness to NSAIDs.

There is undoubtedly compelling evidence that mast cells are activated during the intolerance reaction. Thus, the aspirin/NSAID-induced asthmatic reaction is associated with the release of histamine [28-30], tryptase [9,29, $30,39], \mathrm{PGD}_{2}[9-12,30]$ and CysLTs [7-13]. There are also histological findings [32] supporting the participation of mast cells in the intolerance reaction. As the number of mast cells in sputum is very low, this may have contributed to the difficulties we experienced in this study to elicit the intolerance reaction ex vivo in isolated sputum cells.

On the other hand, the present study provides further evidence that the basal overproduction of CysLTs that is characteristic of AIA may well be due to the increase in eosinophils that is also typical of the syndrome $[1,2,41$, $42]$. We found that there was a higher eosinophil percentage in sputum samples from subjects with AIA as compared to those with ATA (table 3). On the basis of immunohistochemical data, Cowburn et al. [43] suggested that basal overproduction of CysLTs in AIA is due to increased expression in eosinophils of $\mathrm{LTC}_{4}$ synthase, the enzyme [44] that initiates formation of CysLTs from LTA $\mathrm{LA}_{4}$. However, when we calculated the released amounts of CysLTs from ex vivo ionophore-challenged isolated sputum cells in relation to the number of eosinophils, there was no difference between the AIA and ATA groups. This observation agrees with our previous report in isolated blood cells and un-stimulated sputum samples [13] and would argue that the increased baseline formation of CysLTs in than increased formation in each eosinophil. It may be that the understanding of mechanisms in the AIA syndrome requires a distinction between the baseline condition and the intolerance reaction upon exposure to NSAIDs; that is, the different components of the aspirin triad may not be explained by one and the same mechanism. Taken together, the present and previous studies

suggest that the solution to the aspirin/NSAID intolerance mystery lies within the affected target tissues, which in fact may also clarify the clinically established fact that reactions in skin and airways differ in several respects [23]. The study results lend indirect support for the view that derangements in mast cell control are a central component of the adverse reaction.

In summary, the aspirin/NSAID intolerance demonstrated in vivo was not replicated when isolated sputum cells from the same subjects were challenged ex vivo. However, sputum cells from AIA patients released greater amounts of CysLTs in response to ionophore challenge, and sputum cell supernatants had higher concentrations of CysLTs, lending further support to the notion that subjects with AIA have a global overproduction of CysLTs. The data support the interpretation that the higher levels of CysLTs in AIA compared with ATA are due to higher eosinophil counts. We conclude that at present there is no simple in vitro test to diagnose AIA but that ex vivo stimulation of sputum cells nevertheless may become a new method to assess the capacity for CysLT production in the airways of subjects with asthma and other diseases. Future studies will be needed to compare the value of this approach with direct measurements in sputum supernatants.

\section{Acknowledgements}

We thank Marianne Eduards, Elisabeth Henriksson and AnnSofie Lantz for technical assistance and Dr. Nurdan Sandalci for participation in the clinical examinations.

This work was funded by The Swedish Medical Research Council, Heart-Lung Foundation, Asthma and Allergy Foundation, the Stockholm County Council (ALF), the Research Council of HMQ Sophiahemmet, Vinnova (Chronic Inflammation - Diagnosis and Therapy) and the Karolinska Institutet. AIA is due to increased numbers of eosinophils rather

References
Int Arch Allergy Immunol 2012;158:299-306

\footnotetext{
- 1 Szczeklik A, Nizankowska E, Duplaga M: Natural history of aspirin-induced asthma. AIANE Investigators. European Network on Aspirin-Induced Asthma. Eur Respir J 2000; 16:432-436.

-2 Stevenson DD, Szczeklik A: Clinical and pathologic perspectives on aspirin sensitivity and asthma. J Allergy Clin Immunol 2006; 118:773-786, quiz 787-788.

3 Dahlén B, Szczeklik A, Murray JJ: Celecoxib in patients with asthma and aspirin intolerance. The Celecoxib in Aspirin-Intolerant Asthma Study Group. N Engl J Med 2001; 344:142.
} 
-4 Szczeklik A, Nizankowska E, Bochenek G, Nagraba K, Mejza F, Swierczynska M: Safety of a specific COX-2 inhibitor in aspirin-induced asthma. Clin Exp Allergy 2001;31: 219-225.

5 Stevenson DD, Simon RA: Lack of cross-reactivity between rofecoxib and aspirin in aspirin-sensitive patients with asthma. J Allergy Clin Immunol 2001;108:47-51.

6 Gyllfors P, Bochenek G, Overholt J, Drupka D, Kumlin M, Sheller J, Nizankowska E, Isakson P, Mejza F, Lefkowith J, Dahlén SE, Szczeklik A, Murray J, Dahlén B: Biochemical and clinical evidence that aspirin-intolerant asthmatic subjects tolerate the cyclooxygenase 2-selective analgetic drug celecoxib. J Allergy Clin Immunol 2003;111: 1116-1121.

7 Christie PE, Tagari P, Ford-Hutchinson AW, Charlesson S, Chee P, Arm JP, Lee TH: Urinary leukotriene $\mathrm{E}_{4}$ concentrations increase after aspirin challenge in aspirin-sensitive asthmatic subjects. Am Rev Respir Dis 1991; 143:1025-1029.

8 Kumlin M, Dahlén B, Björck T, Zetterström $\mathrm{O}$, Granström E, Dahlén SE: Urinary excretion of leukotriene $\mathrm{E}_{4}$ and 11-dehydrothromboxane $B_{2}$ in response to bronchial provocations with allergen, aspirin, leukotriene $\mathrm{D}_{4}$ and histamine in asthmatics. Am Rev Respir Dis 1992;146:96-103.

-9 Sladek K, Szczeklik A: Cysteinyl leukotrienes overproduction and mast cell activation in aspirin-provoked bronchospasm in asthma. Eur Respir J 1993;6:391-399.

10 O’Sullivan S, Dahlén B, Dahlén S-E, Kumlin $M$ : Increased urinary excretion of the prostaglandin $\mathrm{D}_{2}$ metabolite 9 alpha, 11 betaprostaglandin $\mathrm{F}_{2}$ after aspirin challenge supports mast cell activation in aspirin-induced airway obstruction. J Allergy Clin Immunol 1996;98:421-432.

- 11 Mita H, Endoh S, Kudoh M, Kawagishi Y, Kobayashi M, Taniguchi M, Akiyama K: Possible involvement of mast-cell activation in aspirin provocation of aspirin-induced asthma. Allergy 2001;56:1061-1067.

-12 Higashi N, Taniguchi M, Mita H, Kawagishi Y, Ishii T, Higashi A, Osame M, Akiyama K: Clinical features of asthmatic patients with increased urinary leukotriene $\mathrm{E}_{4}$ excretion (hyperleukotrienuria): involvement of chronic hyperplastic rhinosinusitis with nasal polyposis. J Allergy Clin Immunol 2004; 113:277-283.

-13 Gaber F, Daham K, Higashi A, Higashi N, Gülich A, Delin I, James A, Skedinger M, Gyllfors P, Nord M, Dahlén SE, Kumlin M, Dahlén B: Increased levels of cysteinyl-leukotrienes in saliva, induced sputum, urine and blood from patients with aspirin-intolerant asthma. Thorax 2008;63:1076-1082.

14 Christie PE, Smith CM, Lee TH: The potent and selective sulfidopeptide leukotriene antagonist, SK\&F 104353, inhibits aspirin-induced asthma. Am Rev Respir Dis 1991;144: 957-958.
15 Dahlen B, Kumlin M, Margolskee DJ, Larsson $\mathrm{C}$, Blomqvist $\mathrm{H}$, Williams VC, Zetterström O, Dahlén S-E: The leukotriene-receptor antagonist MK0679 blocks airway obstruction induced by inhaled lysine-aspirin in aspirin-sensitive asthmatics. Eur Respir J 1993;6:1018-1026.

16 Dahlén B, Nizankowska E, Szczeklik A, Zetterström O, Bochenek G, Kumlin M, Mastalerz L, Pinis G, Swanson LJ, Boodhoo TI, Wright S, Dubé LM, Dahlén S-E: Benefits from adding the 5-lipoxygenase inhibitor zileuton to conventional therapy in aspirinintolerant asthmatics. Am J Resp Crit Care Med 1998;157:1187-1194.

-17 Dahlén S-E, Malmström K, Nizankowska E, Dahlén B, Kuna P, Kowalski M, Lumry WR, Picado C, Stevenson DD, Bousquet J, Pauwels R, Holgate ST, Shahane A, Zhang J, Reiss TR, Szczeklik A: Improvement of aspirin-intolerant asthma by montelukast, a leukotriene receptor antagonist. A randomized, double-blind, placebo controlled trial. Am J Respir Crit Care Med 2002;165:9-14.

18 Williams WR, Pawlowicz A, Davies BH: In vitro tests for the diagnosis of aspirin-sensitive asthma. J Allergy Clin Immunol 1990; 86:445-451.

19 Celik GE, Schroeder JT, Hamilton RG, Saini SS, Adkinson NF: Effect of in vitro aspirin stimulation on basophils in patients with aspirin-exacerbated respiratory disease. Clin Exp Allergy 2009;39:1522-1531.

20 Boniface S, Koscher V, Mamessier E, El Biaze M, Dupuy P, Lorec AM, Guillot C, Badier M, Bongrand P, Vervloet D, Magnan A: Assessment of T lymphocyte cytokine production in induced sputum from asthmatics: a flow cytometry study. Clin Exp Allergy 2003;33: 1238-1243.

21 Cho SH, Stanciu LA, Holgate ST, Johnston SL: Increased interleukin-4, interleukin-5, and interferon-gamma in airway CD4+ and CD8+ T cells in atopic asthma. Am J Respir Crit Care Med 2005;171:224-230.

22 Pleskow WW, Stevenson DD, Mathison DA, Simon RA, Schatz M, Zeiger RS: Aspirin desensitization in aspirin-sensitive asthmatic patients: clinical manifestations and characterization of the refractory period. J Allergy Clin Immunol 1982;69:11-19.

23 Nizankowska-Mogilnicka E, Bochenek G, Mastalerz L, Swierczynska M, Picado C, Scadding G, Kowalski ML, Setkowicz M, Ring J, Brockow K, Bachert C, Wohrl S, Dahlén B, Szczeklik A: EAACI/GA2LEN guideline: aspirin provocation tests for diagnosis of aspirin hypersensitivity. Allergy 2007;62:1111-1118.

24 Paggiaro PL, Chanez P, Holz O, Ind PW, Djukanović R, Maestrelli P, Sterk PJ: Sputum induction. Eur Respir J Suppl 2002;37: 3-8.
25 Czech W, Schöpf E, Kapp A: Release of sulfidoleukotrienes in vitro: its relevance in the diagnosis of pseudoallergy to acetylsalicylic acid. Inflamm Res 1995;44:291-295.

26 Pierzchalska M, Mastalerz L, Sanak M, Zazula M, Szczeklik A: A moderate and unspecific release of cysteinyl leukotrienes by aspirin from peripheral blood leucocytes precludes its value for aspirin sensitivity testing in asthma. Clin Exp Allergy 2000;30:17851791.

27 Capron A, Joseph M, Ameisen JC, Capron M, Pancré V, Auriault C: Platelets as effectors in immune and hypersensitivity reactions. Int Arch Allergy Appl Immunol 1987;82:307312 .

28 Stevenson DD, Arroyave CM, Bhat KN, Tan EM: Oral aspirin challenges in asthmatic patients: a study of plasma histamine. Clin Allergy 1976;6:493-505.

29 Bosso JV, Schwartz LB, Stevenson DD: Tryptase and histamine release during aspirin-induced respiratory reactions. J Allergy Clin Immunol 1991;88:830-837.

30 Ferreri NR, Howland WC, Stevenson DD Spiegelberg HL: Release of leukotrienes, prostaglandins, and histamine into nasal secretions of aspirin-sensitive asthmatics during reaction to aspirin. Am Rev Respir Dis 1988; 137:847-854.

31 Picado C, Ramis I, Rosellò J, Prat J, Bulbena O, Plaza V, Montserrat JM, Gelpí E: Release of peptide leukotriene into nasal secretions after local instillation of aspirin in aspirinsensitive asthmatic patients. Am Rev Respir Dis 1992;145:65-69.

- 32 Nasser S, Christie PE, Pfister R, Sousa AR, Walls A, Schmitz-Schumann M, Lee TH: Effect of endobronchial aspirin challenge on inflammatory cells in bronchial biopsy samples from aspirin-sensitive asthmatic subjects. Thorax 1996;51:64-70.

33 Wang XS, Wu AY, Leung PS, Lau HY: PGE suppresses excessive anti-IgE induced cysteinyl leucotrienes production in mast cells of patients with aspirin exacerbated respiratory disease. Allergy 2007;62:620-627.

34 Bianco S, Robuschi M, Damonte C, Simone P, Vaghi A, Pasargiklian M: Bronchial response to nonsteroidal anti-inflammatory drugs in asthmatic patients. Prog Biochem Pharmacol 1985;20:132-142.

35 Pierzchalska M, Szabó Z, Sanak M, Soja J, Szczeklik A: Deficient prostaglandin $\mathrm{E}_{2}$ production by bronchial fibroblasts of asthmatic patients, with special reference to aspirininduced asthma. J Allergy Clin Immunol 2003;111:1041-1048.

- 36 Roca-Ferrer J, Garcia-Garcia FJ, Pereda J, Perez-Gonzalez M, Pujols L, Alobid I, Mullol J, Picado C: Reduced expression of COXs and production of prostaglandin $\mathrm{E}_{2}$ in patients with nasal polyps with or without aspirinintolerant asthma. J Allergy Clin Immunol 2011;128:66-72. 
-37 Harrington LS, Lucas R, McMaster SK, Moreno L, Scadding G, Warner TD, Mitchell JA: COX-1, and not COX-2 activity, regulates airway function: relevance to aspirin-sensitive asthma. FASEB J 2008;22:4005-4010.

38 Nasser SM, Patel M, Bell GS, Lee TH: The effect of aspirin desensitization on urinary leukotriene $\mathrm{E}_{4}$ concentrations in aspirinsensitive asthma. Am J Respir Crit Care Med 1995;151:1326-1330.

- 39 Katial RK, Strand M, Prasertsuntarasai T, Leung R, Zheng W, Alam R: The effect of aspirin desensitization on novel biomarkers in aspirin-exacerbated respiratory diseases. J Allergy Clin Immunol 2010;126: 738-744.
40 Steinke JW, Culp JA, Kropf E, Borish L: Modulation by aspirin of nuclear phospho-signal transducer and activation of transcription 6 expression: possible role in therapeutic benefit associated with aspirin desensitization. J Allergy Clin Immunol 2009;124:724-730.

41 Salén EB, Arner B: Some views on the aspirin-hypersensitivity allergy group. Acta $\mathrm{Al}$ lergol 1948;1:47-84.

42 Samter M, Beers RF Jr: Intolerance to aspirin. Clinical studies and consideration of its pathogenesis. Ann Intern Med 1968;68:975983.
43 Cowburn AS, Sladek K, Soja J, Adamek L, Nizankowska E, Szczeklik A, Lam BK, Penrose JF, Austen FK, Holgate ST, Sampson AP: Overexpression of leukotriene $\mathrm{C} 4$ synthase in bronchial biopsies from patients with aspirin-intolerant asthma. J Clin Invest 1998; 101:834-846.

44 Martinez Molina D, Wetterholm A, Kohl A, McCarthy AA, Niegowski D, Ohlson E, Hammarberg T, Eshaghi S, Haeggström JZ, Nordlund P: Structural basis for synthesis of inflammatory mediators by human leukotriene $\mathrm{C}_{4}$ synthase. Nature 2007;448:613616 . 